\title{
A FACE NEGRA DE ALEXANDRE HERCULANO: VISÕES HISTÓRICAS DO MAL NA CONSTRUÇÃO DO SOBRENATURAL EM "A DAMA PÉ DE CABRA"
}

\author{
Ana Márcia Alves Siqueira \\ Felipe Hélio da Silva Dezidério \\ (Universidade Federal do Ceará)
}

\section{RESUMO}

Gênero que desperta interesses distintos na história e na crítica literária, a literatura noir, como ficaram conhecidas as histórias sobrenaturais do século XIX, apresenta diversas vertentes ainda não exploradas. Em Portugal, Alexandre Herculano consolida-se como o precursor das novelas históricas, resultantes da harmonia de seu trabalho de recolha das fontes históricas lusitanas e de seu projeto estético romântico. A obra de Herculano, contudo, revela um lado sombrio pouco estudado, influência do conto noir francês, das baladas de terror inglesas e das narrativas tétricas alemãs. O presente trabalho propõe-se a analisar os processos de construção da atmosfera negra no conto "A Dama Pé de Cabra", bem como investigar a estratégia de conciliação da visão sobre o Mal da medievalidade em projeto romântico.

PALAVRAS-CHAVE: Literatura negra; Alexandre Herculano; Mal.

\section{ABSTRACT}

Genre which evokes distinct interests in the history and in the literary critic, the noir literature, as it is known the supernatural stories of the XIX century, presents various branches not yet explored. In Portugal, AlexandreHerculano consolidates himself as the precursor ofhistorical novels, result of the harmony between his work collecting Portuguese historical sources and his romantic esthetic project. His works, however, reveal a dark side little studied, influenced by the French noir short stories, the English horror ballad, and the German macabre narratives. This work, therefore, proposes to investigate the processes of construction of dark atmospherein short story "A DamaPé de Cabra" as well as to investigate how the author conciliates the compression of medieval Evil in a romantic project.

KEYWORDS: Dark literature; Alexandre Herculano; Evil. 


\section{HERCULANO E A LITERATURA NEGRA LUSITANA}

O horror e o sobrenatural são temas recorrentes a toda história literária, aparecendo em maior ou menor grau segundo as demandas e exigências de cada época. A literatura portuguesa está repleta de acontecimentos e desastres que inspiram terror em seus leitores. No entanto, esse lado terrível da escrita lusitana é tomado, frequentemente, como um termo acessório ou um requinte de estilo, sendo de interesse a boa parte dos críticos os aspectos estético-formais da produção dos autores ou os reflexos da sociedade na literatura, caso, por exemplo, dos estudos sobre Alexandre Herculano.

No contexto romântico, o escritor inscreve-se como um dos nomes de maior importância entre os escritores portugueses do século XIX, sendo considerado "o homem de maior prestígio intelectual e moral de sua geração” (COELHO, 1984, v. 2, p. 303). Todavia, é pouco conhecido o interesse de Herculano pelo sobrenatural, desde sua formação, visto que, em seus primeiros momentos, o autor aventurava-se a criar versões em português de célebres baladas macabras, como "Noiva do Sepulcro", poema segundo informa o autor, "imitado do inglez" "Afonso e Isolina", de Lewis, e "Caçador feroz" e "Leonor", de Bürger, presentes na terceira parte da obra Poesias, de 1850.

$\mathrm{O}$ aspecto mais conhecido e estudado da obra de Herculano, por ser considerado seu introdutor em Portugal, é o romance histórico, inspirado em lendas medievais, devido, especialmente, à influência da obra de Walter Scott e ao desenvolvimento de estudos históricos que despertaram seu interesse por épocas, fatos e personagens pouco conhecidas. Ao lado de seu incansável trabalho de historiador e organizador da memória nacional, a criação literária serviu como um modo de relembrar o passado mítico e lendário de Portugal sem ferir sua concepção de historiografia. A respeito de sua preocupação com o passado histórico e com as raízes medievais de Portugal, bem como a tradição negra ${ }^{1}$, assinala Maria Leonor Machado de Sousa:

O Romantismo português foi essencialmente medievalista. Simplesmente, essa tendência não se manifestou com grande força no aspecto que agora nos interessa. Foram "góticos" o teatro e a balada, mas não o romance, com excepção de Castilho, por vezes Herculano, e pouco mais. (SOUSA, 1978, p. 168)

Embora o autor não dê relevo à temática sobrenatural em seus romances - o que não impede que haja um clima de tensão e mistério provocado pelas descrições de ambientes tétricos, melancólicos e silenciosamente solitários, como em Eurico, o presbitero e O monge de Cister, -, ela está presente nos contos inspirados em diferentes relatos e manuscritos medievais, assim como na poesia, especialmente nas versões que fez das mais conhecidas baladas macabras europeias publicadas na Revista Panorama, entre 1837 e 1839, e posteriormente no volume Poesias, de 1850. 
Em sua juventude, Alexandre Herculano se liga ao movimento romântico, em parte, graças a seu contato com a Marquesa de Alorna, precursora do Romantismo em Portugal com suas traduções de obras inglesas e alemãs. Ela o incentivou a estudar alemão e descobrir escritores da língua, como Schiller e Goethe, fato facilitado pelo período de exílio na Inglaterra e na França.

Sob a influência de Herculano, em seu trabalho de divulgação da literatura negra, o Romantismo português misturou o horror da literatura alemã, com tendências à exposição do horripilante e do fúnebre - a exemplo dos espectros e cadáveres das baladas de Bürger -, o gótico inglês, inspirado em Lewis e Scott com seus castelos e ruínas, e o romance noir francês, caracterizado pela construção de uma atmosfera soturna, misteriosa e triste. Ou seja, a escola romântica portuguesa ambientou simultaneamente essas tendências, misturando as características dos estilos ao espírito lusitano, segundo esclarece Sousa:

Oromântico português conheceu, sem transição, a literatura nocturnae sepulcral e a de evocações góticas: a meditação reforçada por um temperamento saudosista, levou a encarar os tempos passados de um modo especialmente "romântico", tendendo mais para um negro melancólico e suavemente triste do que para lances arrepiantes da escola alemã, por exemplo. Esta combinação de tendências poéticas e romanescas resultou a quase completa ausência de novelas de aventuras tenebrosas e o aparecimento de obras difíceis de classificar. (SOUSA, 1978, p. 168)

Com efeito, o passado sob a perspectiva romântica lusitana é desenhado por cores melancólicas e reflexivas. Esse apelo melancólico é ainda reforçado pelo caráter essencialmente saudosista do Romantismo português, cuja marca se inscreve em produções com características góticas, no teatro, na balada e no conto, gêneros divulgados em boa parte pela atuação dos periódicos, como a revista O Panorama, na qual Alexandre Herculano publicou, de modo espaçado, tanto as versões de baladas medievais, poemas soturnos e tumulares, de lavra própria, como também contos diversos reunidos posteriormente em Lendas e Narrativas (1851).

O conto "A Dama Pé de Cabra" (HERCULANO, 1952), presente nesta coletânea, revela a face negra do autor, recriando o tom tenebroso do romantismo inglês e do alemão, difundidos pela novela gótica e o conte noir francês, repletos de obscuridade, barulhos, vozes e sombras misteriosas, transfigurações tenebrosas e feitos imprevistos. Também revela a essência saudosista ancorada na tradição nacional que pode ser verificada no subtítulo "Rimance de um Jogral", pois, rimance é uma forma arcaica de romance, termo correspondente na literatura peninsular à balada europeia, curto poema épico cantado e transmitido pela tradição oral, habitualmente usado para contar histórias antigas e tétricas (SOUSA, 1979, p. 50).

Assim, o escritor recria a história do casamento entre a Dama Pé de Cabra, bela mulher encontrada na floresta, e D. Diogo Lopes, iniciando uma nobre linhagem da Biscaia que tem como marca a proteção dos pode- 
res mágicos da misteriosa dama. A narração, unindo oralidade, mistério e insólito, tem início com um sugestivo convite:

Vós os que não credes em bruxas, nem em almas penadas, nem nas tropelias de Satanás, assentai-vos aqui ao lar, bem juntos ao pé de mim, e contar-vos-ei a história de D. Diogo Lopes, senhor de Biscaia.

E não me digam no fim: - "Não pode ser." - Pois eu sei cá inventar cousas destas? Se a conto, é porque a li num livro muito velho, quase tão velho como o nosso Portugal. (HERCULANO, 1952, p. 217)

O escritor, neste conto, usa os procedimentos da escola gótica presentes nas baladas que traduziu e nos recursos descritivos de atmosferas tétricas utilizados por Scott: o castelo e a floresta isolados, as vozes misteriosas, a noite profunda e, principalmente, as lutas e as angústias interiores de seus personagens. Vale ressaltar que a tendência a amenizar a construção do medo nas histórias sobrenaturais, evitando cenas de horror nauseante, é herança do romantismo inglês, que, dentre as outras vertentes, mais se aproxima do estilo de Herculano, como o posto por Robert Muchembled:

À diferença dos frenéticos, que tendiam a acentuar o terror em suas narrativas, outros escritores dos anos de $1824 \mathrm{e}$ 1830 desenvolvem uma abordagem histórica e folclórica, mais distanciada, sob influência de Walter Scott, que considera os espectros, demônios, anões e feiticeiros como reflexos da crença popular de uma determinada época. (MUCHEMBLED, 2001, p. 249)

Desse modo, os aspectos tétricos da narrativa de Alexandre Herculano constituem, fundamentalmente, uma interpretação histórica de um tema específico - a união de um nobre com uma dama fabulosa da floresta - que compõe a tradição portuguesa registrada em Livros de Linhagens. Embora essa tradição seja medieval, a interpretação do autor já não condiz com os esquemas mentais da medievalidade. $\mathrm{O}$ discurso histórico na visão romântica "deixa de ser meramente descritivo e repetitivo, para se tornar basicamente tanto interpretativo quanto formativo, genético" (GUINSBURG, 2002, p. 15). Assim, o resgate do passado feito pelo escritor é idealizado e atende às exigências da mentalidade romântica de sua época, apresentando uma visão fragmentada do imaginário medieval.

Mentalidade e imaginário são termos operativos da Escola dos Anais, vertente da historiografia que utiliza como fontes as diversas representações culturais de uma dada sociedade. Para o historiador Hilário Franco Júnior, mentalidade é a instância mais profunda da percepção, comum a todo o gênero, enquanto imaginário é a instância responsável pela decodificação e representação cultural dessa percepção.

Segundo seu raciocínio, imaginário é "um sistema de imagens que exerce função catártica e construtora da realidade e identidade coletiva ao aflorar e traduzir sentimentos profundos de substratos psicológicos de lon- 
guíssima duração" (FRANCO JÚNIOR, 2003, p. 97-98).Ou seja, enquanto a mentalidade, por ser um denominador psicológico comum da espécie humana, não individualiza nem personalidades nem grupos, os imaginários, formas próprias de os homens verem o mundo e a si mesmos, criam e mantêm grupos, bem como despertam a consciência social. Os imaginários, portanto, nascem, vivem e morrem segundo a necessidade de compreensão do mundo de uma dada sociedade e, por isso, não devem ser confundidos com a atividade psíquica pessoal da imaginação, que é individual.

A coletânea de contos Lendas e Narrativas revela claramente a interligação entre os trabalhos de escritor e de historiador exercidos por Herculano, que publicou a primeira edição íntegra do Livro de Linhagens do Conde D. Pedro (1340) e várias outras obras e documentos medievais reunidos na coleção Portugalia e Monumenta Historica (1856-1867), uma vez que sete das nove narrativas constituintes desta coletânea possuem temáticas medievais claramente inspiradas no material histórico recolhido na coleção.

A base do conto "A Dama Pé de Cabra"2 é aproveitada do título IX do Livro de Linhagens do Conde D. Pedro, a respeito das narrações de "História de D. Diego Lopez e a Dama" e "História de Iñigo Guerra e a Dama”. O conto apresenta ainda algumas referências históricas desses relatos, como as alusões a D. Froom, bisavô de D. Diego e primeiro senhor de Biscaia, e a inimizade dos senhores de Biscaia com o reino de Leão e a cidade de Nastúrio.

Alexandre Herculano aproveitou a narrativa genealógica carregada de sugestões alusivas ao imaginário medieval e sua relação com as manifestações do sobrenatural, criando uma obra ficcional filiada ao fantástico, mas de feição gótica, produto de um projeto estético-filosófico romântico.

Importa salientar o jogo entre veracidade e verossimilhança produzido pelo conto que apresenta personagens históricas em eventos fantásticos e lendários, projetando por sobre estes uma atmosfera de veracidade, tendo em vista que a narrativa do Livro de Linhagens do Conde D. Pedro é um documento histórico, apesar de seu conteúdo lendário sobre genealogias das famílias portuguesas do medievo ${ }^{3}$.

\section{DE FADAS A DEMÔNIOS: UM PROCESSO DE CONVERSÃO}

À primeira vista, a narrativa parece se configurar como uma "história de bruxas" produzida ao sabor do interesse romântico pelo obscuro, maravilhoso ou insólito dos tempos medievais. Todavia, observando atentamente o contexto em que a narrativa está inserida e seus possíveis significados, percebemos tratar-se, na verdade, de obra significativa para a compreensão do processo de transformação de um mito em lenda, como também do processo de tradicionalização desse relato lendário, segundo as transformações da sociedade ao longo dos séculos, especialmente aquelas relativas à propagação do cristianismo e ascensão do poder da Igreja. 
Através da análise da história da Dama Pé de Cabra, inserida no contexto da época e de sua comparação com o mito literário ${ }^{4}$ de Melusine, conhecido em toda a Europa, o conto se mostra rico de significados não revelados pela interpretação tradicional. Tanto o conto de Herculano como a narrativa genealógica são tributários da tradição melusiana, cujo esquema narrativo foi trabalhado, primeiramente, por Dumézil que os denominou "contos melusianos", em homenagem à personagem mais famosa.

Esses relatos possuem uma estrutura comum: há um encontro entre o ser divino de forma híbrida- fada ou deusa que é metade mulher, metade animal - e um ser humano que se apaixona (nas versões medievais, geralmente um cavaleiro durante uma caçada). A misteriosa mulher aceita casar-se com a condição de obediência a um interdito. A união traz prosperidade (riquezas, descendência). Quando o pacto é quebrado, ela desaparece revelando sua verdadeira forma (BRUNEL, 1988, p. 1001).

Amplamente atestados na cultura folclórica universal, tais contos aparecem registrados na literatura do Ocidente medieval nos séculos XII e XIII, quando passam a apresentar essas fabulosas jovens de duas formas: ora desempenham o papel de fadas madrinhas, frequentes na épica, que vaticinam os heróis para aventuras gloriosas e os auxiliam, ora surgem como fadas amantes, que oferecem prosperidade aos eleitos. Geralmente, aparecem acompanhadas por animais dotados de poderes mágicos, ou por velozes cavalos com que, por vezes, presenteiam seus amados. Embora $\mathrm{Me}$ lusine seja o mito literário mais popularizado pela versão de Jean d'Arras, Le roman de Mélusine (1392), estes relatos foram introduzidos na cultura erudita do medievo com o aproveitamento do folclore e da tradição oral de variadas origens empreendido por autores e organizadores de recolhas de anedotas, contos e lendas (cf. LE GOFF e LADURIE, 1971).

Concomitantemente ao processo de variação e transformação das narrativas e das sociedades, ao longo dos séculos, ocorreu a propagação do cristianismo por toda a Europa e a perseguição aos cultos e às práticas pagãs anteriores a ele, ocasionando uma mescla entre imaginários e simbolismos em diferentes graus, dependendo da época e da sociedade. Nogueira explica que, nesse longo e complexo processo, "as superposições das práticas cristãs aos ritos pagãos se realizavam sempre que estes eram de natureza propícia a serem santificados" (NOGUEIRA, 2002, p. 36). Por outro lado, "tudo o que ele repeliu energicamente como demasiado pagão, como contrário a seus dogmas, como impuro e ímpio, refugiou-se no reino do Mal. Aos demônios foram emprestadas as imagens que os antigos atribuíam às divindades" (NOGUEIRA, 2002, p. 36), por exemplo, os chifres e os pés de bode do deus Pã que passam a ser atributos do diabo.

O processo de endemoniamento das damas da floresta ocorreu paralelamente ao de sua apropriação pelas linhagens nobres, em decorrência de uma grande variação de juramentos, desde a promessa de o cavaleiro não ver a bela tomando banho ou durante o sábado até os interditos claramente anticristãos, como deixar de se benzer, de ir à missa ou de aspergir água benta. 
As antigas deusas da natureza, transformadas em fadas, são identificadas, então, a fadas-demônio (algumas vezes até caracterizadas como feiticeiras ou bruxas), aspecto responsável pela ocorrência de significativas variantes. Isto porque, para a concepção da época, as explicações fornecidas pelo cristianismo eram coerentes. Assim, a caracterização demoníaca explica, aos olhos dos clérigos medievais, a natureza e a história da misteriosa mulher. Como o mito é mais antigo que o cristianismo, Melusine está ligada, na verdade, a uma deusa da fecundidade celta, a um espírito fertilizador, ou a uma heroína indo-européia, que surge em versões diferentes como metade mulher, metade serpente, sereia ou dragão.

No caso da reinterpretação literária, Herculano privilegiou as temáticas da mitologia cristã já presentes no Livro de Linhagens português; por isso, a Dama é relacionada ao demônio, simbolizado pelos pés de cabra.

As deusas-mãe foram introduzidas no cristianismo sob a forma de Maria. Segundo a Bíblia, ela, ao contrário de Eva, não dá ouvidos à serpente, mas lhe esmaga a cabeça com os pés. A serpente deixa, portanto, de simbolizar a sabedoria para ser a encarnação do espírito do mal. É a partir do mito de Adão e Eva que verificamos a ruptura da aliança do homem com a natureza característica das religiões pagãs. Por conseguinte, os seres híbridos e todas as suas variantes (deusas, fadas, damas da abundância) passam a ser identificadas com demônios femininos criados pelo maravilhoso cristão. Como a terra é considerada a divindade mãe-primordial em variadas culturas, devido à oposição céu, espaço divino, e baixo, espaço infernal, tudo o que se relaciona a ela passa a ser classificado como demoníaco. Corrobora a questão o fato de os cultos aos deuses agrários estarem diretamente relacionados à fertilidade e à sexualidade, aspectos humanos vistos como pecaminosos pela ortodoxia cristã.

\section{UM CONTO DE HORROR: VOZES E TÉCNICAS NARRATIVAS NA CONSTRUÇÃO DO SOBRENATURAL}

Dentre os recursos narrativos manuseados por Herculano para a criação de uma atmosfera misteriosa própria da literatura negra, a interpolação de diferentes vozes narrativas é bastante recorrente, aplicada especificamente em dois momentos: quando Inigo conta a história de seu pai a seu serviçal e quando, dentro desta história, o velho abade conta a história da Dama a D. Diogo. As frequentes interrupções do narrador onisciente dirigindo-se aos narratários reproduzem o manejo da língua e os tópicos habituais de narradores populares que falam para seus expectadores, à maneira dos jograis itinerantes.

Essas técnicas narrativas são utilizadas quando o narrador pretende criar uma atmosfera de veracidade e autoridade a respeito da história contada, chamando a atenção do auditório para os feitos que serão encenados. O narrador cria uma tensão na narrativa com o reforço constante de que os fatos narrados constituem uma realidade empírica. Esse processo é corriqueiro nos contos fantásticos, em que a atmosfera de dúvida e hesitação contribui para a consolidação dos efeitos catárticos. Acerca da manutenção da atmosfera fantástica, Filipe Furtado discorre: 
Tal acontece, por exemplo, no chamado "efeito de recuo", prática de ascendência romântica que consiste em deslocar a acção para o longínquo no tempo (um passado de contornos vagos) ou no espaço (o país exótico ou imaginário). (FURTADO, 1980, p. 57)

Esta técnica está patente no discurso de abertura da obra, o aviso dado pelo narrador para seus expectadores: "Se a conto, é porque a li num livro muito velho. E o autor do livro velho leu-a algures ou ouviu-a contar, que é o mesmo, a algum jogral em seus cantares." (HERCULANO, 1952,p. 217). O recurso também é completado ao término do conto, quando o narrador chama mais uma vez a atenção dos leitores quanto à veracidade da história narrada, apelando para a fé e para o respeito à tradição: "Como não quero improvisar mentiras, por isso não direi nada. Mas a misericórdia de Deus é grande. À cautela rezem por ele um Pater e uma Ave. Se não lhe aproveitar, seja por mim. Amém." (HERCULANO, 1952, p. 249)

A criação do clima de mistério e suspense também é feita com outros recursos narrativos: há diversas referências a vozes e sons estranhos e também o contraste de luz e sombra, que reforçam a atmosfera sombria de certas passagens, como a caçada funesta de Argemiro, na qual o conde busca sua presa em um "vale triste e sombrio: corria pelo meio uma ribeira fria e mal-assombrada.” (HERCULANO, 1952, p. 227)

Por sua vez, os raros momentos "felizes" ocorrem sempre em situações inequívocas, delineadas em espaços luminosos e vitais. Assim, o dia em que D. Diogo decide se encontrar com o velho abade é descrito com um amanhecer alegre e claro, anunciando o tempo de renovação e recomeço na vida do senhor de Biscaia. Do mesmo modo é descrito o dia, quando os senhores de Biscaia escapam das agruras na noite do resgate de D. Diogo.

Outro aspecto presente no conto diz respeito à peculiaridade de a literatura de temática sobrenatural portuguesa não apresentar a hesitação ou a dúvida como principal característica; ao contrário, segundo explica $\mathrm{E}$ M. de Melo e Castro, o caso português defini-se pela:

ênfase no caráter de transgressão das leis físicas ou psicológicas, ou, de um modo geral, das condições tidas como básicas do real quotidiano ou científico. Caráter de transgressão que quase sempre procura ser absoluto e inexplicável, assumindo assim inteiramente o horror ou o maravilhoso, talvez como características de uma extrarealidade coabitando connosco ou perfeitamente verossímil perante a realidade sensível imediata e verificável, com a qual colide e que muitas vezes transgride ou altera em momentos únicos e privilegiados. (CASTRO, 1974, p. 16)

O conto em estudo é anticonvencional e desconcertante porque se inicia refutando qualquer dúvida ou hesitação do leitor. Contrariamente à regra geral das narrativas fantásticas, o narrador pede a credulidade de seus ouvintes, e da mesma forma as personagens não hesitam diante das manifestações do sobrenatural. D. Diogo não duvida diante da metamorfose sofrida pela Dama após quebrar o juramento e se benzer e, até mes- 
mo, busca saber mais sobre sua estranha esposa. Da mesma maneira, Inigo Guerra aceita a condição extraordinária da mãe e, por isso, decide pedir a ajuda dela para libertar o pai.

Em contrapartida, Herculano abusa dos elementos horríveis, tais como a terrível aparência da Dama: "E a mão da dama era preta e luzidia, como o pello da podenga, e as unhas tinham-se-lhe estendido bom meio palmo e recurvado em garras." (HERCULANO, 1952, p. 222); a descrição do lugar, referido anteriormente, no qual uma voz misteriosa amaldiçoa o conde Argemiro; a transformação do fabuloso animal diante de um cruzeiro: "O onagro, ao sacudi-los de si, soltara um rugido de besta-fera. Sentiram então um cheiro intolerável de enxofre e de carvão de pedra inglês, que logo se percebia sercousa de Satanás." (HERCULANO, 1952, p. 247); ou ainda a vigorosa descrição do inferno:

[...] e depois pela terra dentro, dentro; e depois pelo tecto do inferno, que outra cousa não podia ser um fogo muito vermelho que reverberava daquella profundidade. Tanto era assim, que ainda lá viu passar de relance um demônio com um desconforme espeto nas mãos em que levava um judeu empalado. (HERCULANO, 1952, pp. 247-248)

Além desses excertos, é possível relacionar uma série de outros que aparecem até o final do conto que também remetem ao sobrenatural diabólico, como os feitiços da Dama e a ausência de Inigo nas igrejas.

\section{O MAL RELATIVIZADO EM "A DAMA PÉ DE CABRA"}

Para melhor compreender a ambiguidade entre Bem e Mal em que transita a personagem, perscrutamos o entrelaçamento dos elementos simbólicos dispostos ao longo da trama. O primeiro destes elementos a ser estudado é a floresta, onde acontece o pacto entre os dois personagens centrais: D. Diogo, enquanto caçava, encontra a bela Dama, apaixona-se e a pede em casamento.

Em diversas regiões e culturas, a floresta constitui um verdadeiro santuário. Simbolicamente é um lugar intermediário entre o céu e a terra, entre o natural e o sobrenatural, pois suas raízes prolongam-se através da terra e seus galhos e folhas estão mais próximos do céu. A floresta é local sagrado e domínio das fadas da abundância ou deusas da natureza. Segundo a tradição folclórica, elas sempre aparecem próximas a fontes, penedos, grutas ou em florestas, lugares representativos de sua origem de natureza divina (PIETRO-LASA, 1995). A floresta é também o local sagrado do mito inicial da aliança entre o homem e a natureza. Le Goff acentua o papel da floresta nas aventuras e no imaginário ocidental:

Mas é sobretudo na literatura palaciana que à floresta será atribuído um papel material (no enredo) e simbólico de importância capital. Ela está no centro da aventura cavalheiresca ou, antes, esta encontra nela o seu lugar de eleição. (LE GOFF 1983, p. 47-48) 
A floresta passa a ser um espaço de provações, aquele que adentra seus limites está em constante contado com forças desconhecidas que têm a função de distanciá-lo da virtude, da salvação, como D. Diogo. A floresta constitui no imaginário cristão-medievo um espaço ambivalente de maravilhas e horrores. A zona periférica é um ambiente de transição da cultura - o conhecido, o cultivado - à natureza. A periferia é a moradia dos mitos, do mistério. Como representante periférico, a floresta medieval incorpora o inculto, o desconhecido; é um espaço de provação porque suscita o medo.

Assim, o cavaleiro, caçando, é atraído pela voz de uma bela mulher. Fica encantado ao vê-la e aceita obedecer a uma proibição (tabu) para obtê-la em casamento. É tão forte a paixão que D. Diogo declara, “com os olhos chamejantes": "E se eu te amasse mais que a minha mãe, porque não te cederia qualquer dos seus muitos legados?" (HERCULANO, 1952, p. 218). Embora a Dama exija que o nobre se esqueça "de uma coisa que a boa rica-dona te ensinava em pequenino e que, estando, para morrer, ainda te recordava" (HERCULANO, 1952, p. 219), ele - que "nos folgares e devassidões perdera o caminho do Céu” (HERCULANO, 1952, p. 219) - aceita a aliança apesar do pecado: "De que servem benzeduras? Matarei mais duzentos mouros e darei uma herdade a Santiago. Ela por ela. Um presente ao apóstolo e duzentas cabeças de cães de Mafamede valem bem um grosso pecado" (HERCULANO, 1952, p. 219).

O canto constitui outro elemento observado no encontro da Dama Pé de Cabra com D. Diogo, que ouve a linda voz, fica apaixonado e, imediatamente, propõe casamento à desconhecida - essa temática do encantamento realizado pela música e pela sedução remete-nos à lenda grega sobre as sereias. De acordo com a tradição (CHEVALIER, 1982, p. 888), as sereias simbolizam a sedução mortal e representam as armadilhas nascidas do desejo e da paixão. Como vivem nos elementos instáveis do ar (pássaros) ou do mar (peixes), fazem-se criação do inconsciente, dos sonhos fascinantes e terríveis, em que se delineiam as pulsações obscuras e primitivas do homem.

Nesse ponto, os elementos formam um conjunto inter-relacional: em um local sagrado, intermediário entre dois estágios (céu-terra), irrompem o desejo e a paixão do homem pela beleza do desconhecido. Por causa do desejo despertado pela mulher tentadora, ele aceita, de imediato, a proibição. Esse mesmo sentimento incontrolável, porém, ocasionará a quebra do juramento. A promessa feita, a desobediência e a punição, toda a cena remete ao mito do primeiro casal e está relacionada ao maravilhoso cristão medieval, que se concentra no controle do comportamento das pessoas, de suas pulsões e desejos, principalmente ligados à sexualidade e ao pecado original.

A Dama Pé de Cabra encarna as características de Eva, a responsável pela queda da humanidade. Tal compreensão, no entanto, é resultante de um processo de acumulação e desenvolvimento do imaginário Ocidental, perpassando à tradição clássica com o mito fundador de Pandora, que introduziu todos os males do mundo devido a sua curiosidade. Na tradição cristã, que incorpora o judaísmo à cultura greco-romana, as mulheres já 
eram vistas com suspeita pelos pais da Igreja, dada a inclinação natura daquelas em se opor às intenções divinas e desviar a ordem das coisas. Todas as damas seriam, em maior ou em menor grau, feiticeiras.

Todas sendo mais ou menos feiticeiras, as damas preparam entre si misturas suspeitas, a começar pelas maquiagens, os ungüentos, as pastas depilatórias de que se servem, falseando suas aparências corporais para apresenta-se enganadoras diante dos homens. (DUBY, 2001, p. 13)

Perante os olhos de Deus, essa prática constitui um grande pecado, pois, alterando e escondendo a constituição de seus corpos, as mulheres estariam modificando a criação divina. Sendo Deus o único ser perfeito, e tendo Ele criado o homem a sua imagem e semelhança, modificar o corpo seria negar a perfeição divina.

Lancemos um olhar à Dama que, com a beleza e a voz, encanta o senhor de Biscaia. Tomando pelo desejo, não se incomoda com o fato de ela ter pés deformados: "só quando, à noite, no castelo, pôde considerar miudamente as formas nuas da airosa dama, notou que tinha os pés forcados como os de cabra" (HERCULANO, 1952, p. 219). Tal pormenor anatômico, minimante estranho, não fez, porém, com que o lascivo D. Diogo retrocedesse, visto que, por anos, os dois "viveram em boa paz e união" (HERCULANO, 1952, p. 220).

A Dama tem papel similar ao do demônio, uma vez que ele é a raiz de todo o mal, o grande desvirtuador, sua função é tentar o homem para afastá-lo do caminho da verdade.

Ele odiava Deus e todos os seres humanos, concebidos à imagem divina, e ansiava por capturar o maior número possível de almas em seu reino infernal, para despojálas de sua divina semelhança, vingando-se por sua queda: negando os homens a Deus e Deus aos homens. (NOGUEIRA, 2002, p. 41)

Como o diabo, a Dama atua sobre os homens através da sedução, utilizando-se de subterfúgios que os fazem hesitar em suas convicções. Ela assume certas funções que o folclore europeu atribui a algumas mulheres sobrenaturais de sua espécie: tem poder de bruxa e capacidade de dominar os fenômenos meteorológicos:

Enquanto a dama cantava estas cantigas, o mancebo sentia um quebrantamento nos membros que crescia cada vez mais e que o obrigou a assentar-se. E logo, logo ouviuse um ruído abafado, como de trovões e de ventanias enfolgando-se em covoadas: depois o céu começou de toldar-se, e cada vez era mais cris, até que, enfim, apenas uma luz de crepúsculo o alumiava. E a mansa almácega refervia, e os penedos rachavam, e as árvores torciam-se, e os ares sibilivam. (HERCULANO, 1952, pp. 239-240)

A sociedade cristã Ocidental pós-mileniarista, tomada por um pânico coletivo da presença e da ação do demônio no cotidiano, difundiu no imaginário das "massas o medo eclesiástico das mulheres" (NOGUEI- 
RA, 2004, p. 175). Se o demônio buscava prejudicar alguém ele o faria por intermédio de uma mulher, tendo em vista sua debilidade em resistir aos argumentos do tentador. A bruxa, portanto, é o símbolo da confidente do diabo. Em troca de extravagâncias sexuais com o demônio e seus servos, as mulheres eram instruídas nos mistérios da magia. A fonte do poder das bruxas, em uma sociedade cuja mentalidade encara qualquer intervenção mágica como maléfica, tem por origem o componente sexual, igualmente pecaminoso.

Entretanto, na narrativa literária, embora a Dama tenha proposto um pacto herético com D. Diogo, ela faz feitiços e encantamentos para ajudar seu filho Inigo Guerra a salvá-lo quando foi prisioneiro dos mouros. Surge então a questão: afinal, o que é a Dama Pé de Cabra? Fada ou bruxa? Alma penada ou demônio?

Conforme discutido anteriormente, sob o influxo do cristianismo, as histórias tradicionais e folclóricas, bem como a tradição pagã foram manipuladas com o intuito de demonizar e excluir as antigas religiões. Não há, porém, como apagar algo tão complexo e tão enraizado na alma humana. Assim, o Livro de Linhagens, embora não diga claramente que a misteriosa dama é uma bruxa ou qualquer outra coisa, já apresenta elementos que a Idade Média via como fruto de bruxaria: a ligação com o diabo indiciada pelos pés de cabra e o desaparecimento diante do sinal da cruz, o poder de desaparecer por uma fresta da janela, de presentear o filho com um cavalo maravilhoso que não precisa ser alimentado ou ferrado e, mesmo assim, é capaz de percorrer imensas distâncias em minutos. Todos esses elementos, aliados ao conhecimento de Alexandre Herculano sobre a Idade Média ${ }^{5}$ serviram de inspiração para que ele misturasse "vários ingredientes", aproveitados de diferentes contextos e ligados ao sobrenatural, para compor sua personagem.

De acordo com a concepção medieval, a presença do demônio era uma realidade; "o mal existe, age livremente; tem o poder de seduzir os homens e infestar o seu espírito” (DUBY, 2002, p. 137). Como este ser maligno agia, a Igreja, de acordo com a permissão de Deus, usava sua figura com o intuito de manter os homens no caminho reto. Entretanto, havia uma razão maior para tantos prodígios. No imaginário medieval, a presença do demônio na terra representava, no dia do juízo, o retorno de Cristo que o derrotaria por definitivo. Logo, sinais como pestes, fome e guerras simbolizam a chegada do final dos tempos e a presença do demônio na Terra, por extensão, a vinda do Salvador. Vê-se, portanto, que a figura maligna revela uma natureza dúbia, pois, ao passo que demonstra o horror, também representa a esperança.

Já para o desencantado mundo da Modernidade, a presença do diabo e sua existência metafísica são questionadas pelo racionalismo iluminista e materialista, processo que revela o declínio da Igreja, principal patrocinadora do diabo, e a ascensão do Estado Moderno. Essas mudanças são acompanhadas pela Literatura, pois a figura do Diabo horrendo das iluminuras é substituída por um representante mais próximo do humano: o Mefistófeles, de Goethe. 
Pulverizada, a imagem de Satã ia começar a esposar modas, a adaptar-se às evoluções dos costumes e da sociedade. Sua projeção na cena literária ou artística, sob múltiplas facetas, resultou na multiplicação de simbolismos, mas igualmente no enfraquecimento da potência unificadora do mito cristão, que continuava sendo defendido pelos teólogos ortodoxos. (MUCHEMBLED, 2001, p. 244)

Compartilhando dessa visão, Herculano (re)constrói uma parcela cultural do medievo lusitano com fragmentos idealizados de sua atualidade. A Dama Pé de Cabra é a representação viva desta fragmentação, pois admite em si a fada familiar dos bosques pagãos celtas, a figura de um diabo familiar ambíguo, conforme a religiosidade popular portuguesa, que o descreve como um ser não tão perigoso e mais humano (ESPÍRITO SANTO, 1990), imiscuída ainda pela visão do belo horrível apreciado pelos românticos. Conforme explica Mário Praz (1996), a beleza, sob a perspectiva romântica, recebe realce mesmo do que parece contrariá-la - é a estética do horrível que propicia a união entre a beleza, o prazer e a sedução com seu outro aspecto: a corrupção, o horrível ou demoníaco. Nessa perspectiva, a Dama irmana-se à sedução dos vampiros, à beleza somente corrompida no retrato de Dorian Gray, ao fascínio da rebeldia de Fausto.

Enquanto estava sob o encantamento e a sedução da bela Dama, D. Diogo não dá atenção à marca que a assinala como uma criatura diabólica, todavia, quando presencia a rebeldia da podenga, que exibe seus poderes sobrenaturais - era menor que o cão de caça em tamanho e força, mas o mata - e subverte a ordem instituída, o cavaleiro invoca a mãe protetora de todos os cristãos e de seus valores: "À la fé que nunca tal vi! Virgem bendita. Aqui anda cousa de Belzebu.' E, dizendo e fazendo, BENZIA-SE E PERSIGNAVA-SE." (HERCULANO, 1952, p. 221).

A consequência imediata da quebra do interdito é a revelação da verdadeira natureza da Dama, uma criatura demoníaca horrível, e de seu desaparecimento:

- Ui! - gritou sua mulher, como se a houveram queimado.

O barão olhou para ela: viu-a com os olhos brilhantes, as faces negras, a boca torcida e os cabelos eriçados. E ia-se alevantando, alevantando ao ar, com a pobre D. Sol sobraçada debaixo do braço esquerdo [...] e, continuando a subir ao alto, saiu por uma grande fresta... (HERCULANO, 1952, pp. 221-222)

A Dama possui pés de cabra porque é a intermediária entre o homem e o demônio. Ela é a beleza portadora do sexo, da tentação e do pecado; aquela que desobedece e subverte a ordem instituída, a rebelde representante das forças noturnas e indomáveis.

Todavia, a obra literária é rica de significados, se analisarmos a narrativa cronologicamente podemos observar as modificações e substratos do mito utilizados por Alexandre Herculano, como também os substra- 
tos oitocentistas presentes. É na segunda trova, que surge a explicação para a origem da Dama, criação exclusiva do autor, já que o relato do Livro de Linhagens não a fornece.

Esta trova começa com a notícia de que D. Diogo havia caído prisioneiro em Toledo. Como D. Inigo não consegue libertá-lo é aconselhado a solicitar os serviços mágicos de sua mãe. Justificativa para que o cavaleiro conte a história da terrível Dama, originalmente esposa do conde Argemiro, e de sua maldição, registrada em um santoral godo e relatada por um abade a D. Diogo Lopes.

Nessa segunda parte do conto a criatividade do autor explora as consequências de quebras de interditos da moral cristã relacionando-as à temática tradicionalmente motivadora das baladas macabras europeias (presente, inclusive, em Leonor e Afonso e Isolina, baladas traduzidas pelo autor): a separação do casal apaixonado que termina ou em prova de fidelidade, superando a morte, ou em traição, que acarreta uma maldição. Conforme salienta Sousa, esta temática adquire uma importância maior no contexto do Romantismo português, visto que o tema da separação dos casais sempre esteve presente na história portuguesa, desde a necessidade de ir combater castelhanos ou mouros ao embarque nas naus para conquistas de além-mar. (SOUSA, 1979, p. 28).

A primeira promessa feita cronologicamente no conto é um tabu relacionado à aliança do homem com a natureza, já que matar a fêmea condena os filhotes à morte, desequilibrado o ciclo da vida. Além disso, a desobediência ao interdito prejudicaria a manutenção da principal atividade de lazer da nobreza em tempo de paz: a caça. Assim, quando o conde Argemiro, ignorando a promessa feita ao pai, mata um onagro fêmea que cuidava de sua cria, surge uma voz misteriosa advertindo-o: "Uma voz soou então nos ouvidos do conde, e dizia: - 'Orfãos ficaram os cachorrinhos do onagro: mas pelo onagro tu ficarás desonrado." (HERCULANO, 1952, p. 228)

As forças sobrenaturais que se manifestam na narrativa midiatizam as condutas humanas em seus extremos, uma vez que tais fenômenos possuem um caráter ilustrador. Em certos momentos, essas manifestações exercem a função de testar a vontade dos personagens, bem como sua integridade, como o caso do adultério da Condessa com Astrigildo, que cumprem a promessa da voz misteriosa da caverna.

A desonra pública de Argemiro foi realizada como castigo pela transgressão ao juramento feito no leito de morte de seu pai, cuja cláusula única era não caçar animais prenhes ou com filhotes. Pode-se argumentar, portanto, a respeito da inocência e do castigo injusto sofrido pelos dois, uma vez que forças de outra ordem trabalharam para que o casal de amantes se unisse e assim atingisse ao orgulhoso Argemiro. No entanto, um dado que não pode ser posto de lado neste juízo é o livre arbítrio. Mesmo com seu marido em guerra, a Condessa decide se unir ao jovem e festejar a união adúltera nos domínios do esposo ausente. Não resistindo à tentação, ela peca em concupiscência, violando os interditos acerca do sexo e do matrimônio ordenados pela moral cristã, condenando-se, por fim, ao inferno, de onde volta como alma penada, agora transmutada na Dama de pés de cabra. 
Atenta-se também para o fato de os eventos sobrenaturais com características demoníacas, interposto no triângulo Argemiro/Condessa/ Astrigildo, têm por razão exercer uma sanção contra o ato transgressor do conde de Biscaia, retomando o conceito de um mal que trabalha de acordo com as exigências de um bem.

Em todas as maravilhas, em todos os presságios - e mesmo quando o próprio demônio se mostra - convém pois distinguir a mão de Deus. (...) O mal será um castigo? Não será, também, um aviso generoso do Mestre, o qual na sua misericórdia procura prevenir as suas criaturas antes de lançar sobre elas os mais terríveis de seus golpes? (DUBY, 2002, p. 137)

Dessa forma, o mal intervém no cotidiano terreno segundo a vontade do bem, cumprindo a tarefa de elemento tentador, que prova a vontade humana e sua firmeza no caminho justo, bem como o de agente corretivo, que impõe castigos e sofrimentos.

À primeira vista, o conto traz em seu bojo a visão do medievo sobre a mulher, acrescida pela moral, em muito ainda misógina, do século XIX, que, sob a óptica liberal-burguesa, restringia o seu papel ao lar e à criação dos filhos, condenando aquelas que se afastavam deste modelo (ARIĖS, 1981). A despeito das modificações sofridas pela sociedade e de seu desenvolvimento técnico-científico, a mulher continuava a ser definida em consonância com os modelos propostos pela religião cristã: a virgem pura/mãe submissa ou a Eva pecadora, criatura fascinante, que arrasta o homem para a desgraça.

Estes modelos estão prnoesentes na produção romântica em que a mulher desempenha um importante papel, porque pode direcionar o homem para o bem, quando caracterizada como "mulher anjo", ou pode arrastá-lo para o mal, encarnando a "mulher demônio"', sedutora e perigosa por suas atitudes libertárias (PRAZ, 1996). Destacamos, no entanto, outros aspectos a se misturar nessa teia: as correntes pré-românticas e românticas acentuaram a voga do demoníaco. O interesse pelo mal fez com que poetas, escritores e teóricos passassem a discutir o problema sob diferentes perspectivas, embora o foco predominante desse questionamento se voltasse para Lúcifer, figura emblemática e fascinante por sua rebeldia, altivez e liberdade, que "atrairá um pequeno número de ativos adeptos e literatos" (MUCHEMBLED, 2001, p. 254). A propósito, geralmente o herói romântico, caracterizado como um eu rebelde que se debate ante as arbitrariedades da realidade, aparenta-se com o Lúcifer revoltoso de Milton.

O fascínio romântico pelo maligno e sua origem, pela beleza traiçoeira e seus encantos, está fartamente presente na poesia ultra-romântica, no romance negro e no gótico. Segundo Praz (1996), a aspiração romântica tende a se identificar com o místico, o rebelde, o proscrito, o doloroso ou horrível, aspectos que contribuem para que a Dama, a despeito de sua terrível condição satânica, seja vista como uma personagem fascinante e misteriosa, tanto por sua rebeldia, quanto por viver à margem do mundo medieval cristão de forma livre. 
Do mesmo modo, o filho desta fabulosa mulher, Inigo Guerra, transforma-se em um herói ao gosto romântico. Enquanto o relato medieval, sucintamente, refere-se à ajuda proporcionada pela mãe para libertar D. Diogo, dando ao filho um cavalo mágico, que o ajudaria a vencer todas as batalhas ao longo de sua vida, o final da terceira trova do conto destaca a dupla natureza do jovem herói, fruto do bem e do mal.

Conforme a concepção de religiosidade medieval, Inigo estaria se rendendo ao poder de um ente maléfico, mesma criatura que ocasional toda a desgraça de seu pai. Contudo, devido à difícil situação de resgate, somente através de uma mirabilia, de um evento de ordem sobrenatural, tal seria possível. O jovem teme, pois, que, sendo filho da criatura, obviamente tenha uma inclinação para a perdição. Porém, ao estabelecer um acordo com sua mãe, D. Inigo aceita, por fim, sua natureza dupla, ou como Antonio Candido comenta acerca a natureza do herói romântico: "Romanticamente, o demônio confere ao iniciado um sucedâneo da divindade, e o iniciado terá em conseqüência uma natureza dupla, divina e infernal." (2006, p. 18-19).

No caso de D. Inigo, sua mãe faz com que ele consiga realizar a proeza de resgatar seu pai de uma situação impossível pelas vias meramente humanas. No entanto, esta realização custou a quebra consciente das normas cristãs que estavam impostas pelos acordos vigentes. Dos lados que constituíam sua natureza dupla, aquele no qual sua mãe agia foi mais sedutor, e, assim como seu pai, D. Inigo foi vencido por seus desejos, imperativo dos heróis românticos.

\section{À GUISA DE CONCLUSÃO}

Apesar de o narrador encerrar sua narração pedindo que seu público reze pelo herói, o destaque é dado às proezas realizadas por ele: " $\mathrm{E}$ seu nome retumbou em toda a Espanha; porque não houve batalha em que entrasse que se perdesse e nunca em nenhum recontro foi ferido nem derribado." (HERCULANO, 1952, p. 249).

Tal escolha nos leva a concluir que a criação de Herculano compreende a aliança com um ser sobrenatural, fada ou demônio, como perigosa, que implica em castigo, mas também tem suas vantagens, porque traz glória e proteção. Em um contexto guerreiro e incerto, as questões entre o bem e o mal se tornam secundárias. Não se pode deixar de perceber a ironia implícita, nesse jogo de sobreposições de crenças e valores, em que as verdades religiosas são relativizadas pela pena astuta do autor.

Dentro de seu projeto histórico e estético, Alexandre Herculano elabora a narrativa de "A Dama Pé de Cabra", reaproveitando a tradição das narrativas genealógicas, das baladas macabras, e recriando a atmosfera de bruxedos da Idade Média portuguesa. Neste contexto, a literatura negra ou de horror surge com características próprias e bem delimitadas, tendo em vista que os elementos utilizados na elaboração do conto escondem 
relações e esquemas mentais internos bem mais complexos que aqueles apresentados em sua superfície. As impressões sobre o mal presentes no conto são resultado de encontros e misturas de épocas distintas que se congregam e convergem numa única peça artística, sob os influxos românticos de valorização da rebeldia.

Assim, a fabulosa ou demoníaca Dama Pé de Cabra ressurge na recriação da lenda como uma ambígua figura, fruto da eterna disputa entre as práticas culturais e religiosas reinantes. A esse propósito a bela sedutora, cristalização das diferentes deusas, fadas, evas, santas ou demônios, declara: “Culpa?! Não há para mim inocência nem culpa', replicou a dama, rindo às gargalhadas." (HERCULANO, 1952, p. 338)

\section{REFERÊNCIAS BIBLIOGRÁFICAS}

ARIÈS, Philippe. História social da criança e da família. Rio de Janeiro: Guanabara, 1981.

BRUNEL, Pierre. Dictionnaire des mytheslitteraires. Paris: Éditions du Rocher, 1988.

CANDIDO, Antonio. Da vingaça. In: . Tese e antítese. Rio de Janeiro: Ouro sobre Azul, 2006, pp. 15-38.

CASTRO, Ernesto M. de Melo e. Introdução. In: Antologia do conto fantástico português. Lisboa: Afrodite, 1974, pp.10-27.

CHEVALIER, Jean \& GHEERBRANT, Alain. Dictionnaire des symboles. Paris: Robert Laffont /Jupiter, 1982.

COELHO, Jacintho do Prado. Dicionário de literatura. Porto: Porto Figueirinhas, 1984, v. 2.

DUBY, Georges. Eva e os padres: damas do século XII. São Paulo: Companhia das Letras, 2001.

O ano mil. Lisboa: Edições 70, 2002.

ESPÍRITO SANTO, Moisés. A religião popular portuguesa. Lisboa: Assírio \& Alvim, 1990.

FURTADO, Filipe. A construção do fantástico na narrativa. Lisboa: Livros Horizonte, 1980.

FRANCO JÚNIOR, Hilário. O fogo de Prometeu e o espelho de Perseu: reflexões sobre mentalidade e imaginário. In: Signum, São Paulo, n. 5, p. 73-116, 2003.

GUINSBURG, J. O romantismo. 4. ed. São Paulo: Perspectiva, 2002.

HERCULANO, Alexandre. A Dama Pé-de-Cabra. In: Lendas e narrativas. São Paulo: Brasileira, 1952, pp. 215-249.

LE GOFF, Jacques e LADURIE, Le Roy. Mélusine maternelle et défricheuse. In: Annales: Économie, Societéet Civilizations. Paris, v.3-4, n. 26, pp. 590-622, 1971. 
LE GOFF, Jacques. O maravilhoso e o quotidiano no ocidente medieval. Lisboa: Edições 70, 1983.

MUCHEMBLED, Robert. Uma história do diabo: séculos XII -XX. Rio de Janeiro: Bom Texto, 2001.

NOGUEIRA, Carlos Roberto Figueiredo. Bruxaria e história: práticas mágicas no Ocidente cristão.Bauru (SP): Edusc, 2004.

O diabo no imaginário cristão. $2^{\text {a }}$ ed. Bauru (SP): Edusc, 2002.

PIETRO LASA, J. Ramon. Las leyendas de los señores de Vizcaya. Madrid: Fundación Ramón Menéndez Pidal/ Fundación de la Universidad Autónoma de Madrid/ Universidad del País Vasco, 1995.

PRAZ, Mário. A carne, a morte e o diabo na literatura romântica. Campinas: Editora da Unicamp, 1996.

SIQUEIRA, Ana Marcia A. Relações de poder nos Livros de Linhagens portugueses. In: ZIERER, Adriana e FEITOSA, Márcia M. M. (Orgs.) Literatura e história antiga e medieval: diálogos interdisciplinares. São Luís: EDUFMA, 2011.

SOUSA, Maria Leonor Machado. O "horror" na literatura portuguesa. Lisboa: Instituto de Cultura Portuguesa, 1979.

A literatura "negra" ou de terror em Portugal (séculos XVIII e XIX). Lisboa: Novaera, 1978.

(Recebido para publicação em 17/12/2011,

Aprovado em 10/01/2012)

\section{NOTAS}

1 Utilizamos aqui a escolha de Leonor Machado Sousa (1978, p. 11), que adota o termo "negro" para designar toda a literatura desenvolvida em um ambiente com elementos tétricos e obscuros, ou de terror ou mistério, envolvendo o sobrenatural. Essa literatura apresenta ainda ambientes grandiosos e sublimes: cemitérios, antigos castelos e mosteiros, ruínas, e comporta os diferentes nomes de gótico, noir, tétrico, frenético; embora estas definições possuam especificidades características, devido ao curto espaço, não as discutiremos nesse trabalho.

2 Oito anos antes da publicação de Lendas e Narrativas, o conto tinha sido publicado pela primeira vez em folhetim na revista O Panorama, respectivamente nas edições $\mathrm{n}^{\circ} .88, \mathrm{n}$. 91 e n. 95, entre os meses de setembro e outubro de 1843.

3 Para mais informações, ver: Siqueira, 2011.

4 Mito literário é constituído por um relato mítico retrabalhado em uma narração por um autor que a trata e modifica com grande liberdade, podendo, até mesmo, acrescentar-lhe novas significações (BRUNEL, 1988, p. 12).

5 Não podemos esquecer que Herculano escreveu sobre a história da Inquisição em Portugal. 6 A vasta produção novelística de Camilo Castelo Branco oferece um amplo painel de aproveitamento do tema. 